\title{
SEROLOGICAL EVIDENCE OF LEPTOSPIRA SPP. IN THE LAMI TUCO-TUCO RODENTS (CTENOMYS LAMI)
}

\author{
Simone Tostes Oliveira ${ }^{1}$, Gisele Guiomara Stein ${ }^{1}$, Andrea Pires Santos ${ }^{2}$, Alexander \\ Welker Biondo ${ }^{1}$, Joanne Belle Messick², Felix Hilario Diaz Gonzalez ${ }^{3}$ \\ 1 UFPR \\ 2 Purdue University \\ 3 UFRGS \\ Correspondência: Simone Tostes Oliveira: tostesimone@gmail.com.br
}

\begin{abstract}
Although rodents are reportedly the major reservoirs of Leptospira spp. in the wildlife of Brazil, the role of the widely distributed native tuco-tuco rodent (Ctenomys lami) has yet to be determined. Accordingly, a total of 40 serum and eight urine samples from wild $C$. lami were collected from June to September 2008 in the city of Porto Alegre, Southern Brazil. The serum samples were screened using the Microscopic Agglutination Test against 13 Leptospira spp. pathogenic serovars. A polymerase chain reaction (PCR) was performed to detect the presence of leptospiral DNA in the urine samples. Five $(12.5 \%)$ of the serum samples had $\geq 100$ antibody titer levels against one or more of the serovars. None of the urine samples yielded positive PCR amplification. In addition, all animals which had urine samples tested had also negative antibody serum titers. In conclusion, although $C$. lami may be exposed to Leptospira spp., infection may be occasional because no detectable leptospiruria was found.
\end{abstract}

Key Words: leptospirosis; rodent; serology; wildlife; PCR

\section{EVIDÊNCIA SOROLÓGICA DE LEPTOSPIRA SPP. EM LAMI TUCO-TUCOS (CTENOMYS LAMI)}

RESUMO: Apesar dos roedores serem os principais reservatórios de Leptospira spp. da fauna silvestre no Brasil, o papel do roedor nativo tuco-tuco Lami (Ctenomys lami) ainda não foi determinado. Um total de 40 amostras de soro e oito de urina foram coletados de $C$. lami entre junho e setembro de 2008, no Rio Grande do Sul. As amostras de soro foram testadas através do teste de soroaglutinação microscópica (SAM) contra 13 sorovares de Leptospira spp. Reação em cadeia da polimerase (PCR) foi realizada para detectar a presença de DNA de leptospiras patogênicas nas amostras de urina. Cinco (12,5\%) das amostras sorológicas tiveram títulos $\geq 100$ contra um ou mais sorovares. Nenhuma das amostras de urina teve amplificação positiva por PCR; no entanto, estes oito animais eram também soronegativos. Apesar da exposição do C. lami à Leptospira spp., a infecção pode ser ocasional visto que não foi detectada leptospirúria.

Palavras-chave: leptospirose; roedor; sorologia; PCR; fauna silvestre 


\section{INTRODUCTION}

Leptospirosis is a zoonotic bacterial disease that may infect humans and domestic and wild animal species. Rodents have been considered important reservoirs of pathogenic Leptospira serovars (LEVETT, 2001). Although the control of rodents may decrease the risk of transmission to incidental hosts and environmental contamination, environmental maintenance of pathogenic Leptospira spp. causes the spread of leptospirosis in wild animals (GUERRA, 2009).

The tuco-tucos are fossorial rodents belonging to the genus Ctenomys in the family Ctenomyidae, which includes nearly 60 species. They are distributed throughout the southern half of South America (REIG et al., 1990). Lami tuco-tuco (Ctenomys lami) is distributed along a sandy area (Coxilha das Lombas) of Southern Brazil, spreading from the northern coast of Lake Guaíba to an area northwest of the Lagoa dos Barros (FREITAS, 2001). Even though some of these areas are environmentally protected, they are under anthropic impact due to the surrounding livestock production. To the authors' knowledge, there are no published data regarding the occurrence of leptospirosis in C. lami. Accordingly, the aim of this study was to detect evidence of exposure of wild Lami tucotucos to Leptospira spp.

\section{MATERIAL AND METHODS}

A total of 40 adult Lami tuco-tucos were live-trapped from three areas in Rio Grande do Sul State, Brazil from June to September of 2008. Areas A (Distrito de Itapuã, $30^{\circ} 17^{\prime} 31.2^{\prime \prime} \mathrm{S}$, $50^{\circ} 58^{\prime} 31.6^{\prime \prime} \mathrm{O}$ ) and B (Município de Viamão, $30^{\circ} 8^{\prime} 0.8^{\prime \prime}$ S, 50⒌'38.2"O) are livestock production areas and were affected by human inhabitation. Area $\mathrm{C}$ (Município de Viamão, Unidade de
Conservação Refúgio de Vida Silvestre Banhado dos Pachecos, Distrito de Águas Claras, $30^{\circ} 5^{\prime} 31.2^{\prime \prime} \mathrm{S}, \quad 50^{\circ}$ $50^{\prime} 35^{\prime \prime}$ ) was not inhabited by humans. A total of 11,16 and 13 animals were captured from areas A, B and C, respectively.

The Lami tuco-tucos were weighed and anesthetized with intramuscular ketamine (20 mg/kg of body weight). All animals were evaluated and considered to be clinically healthy. Blood was collected from the cranial vena cava, kept in tubes without anticoagulant at room temperature and subsequently centrifuged to obtain serum. Urine samples were successfully collected from eight animals using gentle abdominal hand pressure. After anesthetic recuperation, all animals were released in their respective native tunnels.

Using the Microscopic Agglutination Test (MAT), the presence of anti-Leptospira antibodies was tested in 13 serovars most usually found in Brazil: australis, autumnalis, bratislava, canicola, copenhageni, grippotyphosa, hardjo, icterohaemorrhagiae, hebdomadis, pomona, pyrogenes, tarassovi and wolffi. A titer $\geq 100$ was considered positive.

DNA from the urine samples was extracted in duplicate (LUCCHESI et al., 2004) and a conventional polymerase chain reaction (PCR) was performed to detect pathogenic leptospires using the primer sets G1/G2 and B64-I/B64-II (GRAVEKAMP et al., 1993). Positives urines from dogs for both primer sets and DNA extracted from leptospire's cultures were used as positive controls and included in each run.

\section{RESULTS}

A total of $5 / 40(12.5 \%)$ rodents were seropositive for Leptospira by MAT, with titers of 100 . From area A, two samples were positive for the 
serovar wolffi and one sample had equal titers for the serovars wolffi, hardjo and icterohaemorrhagiae. One sample from area $B$ was seropositive for the serovars copenhageni, grippotyphosa, pomona and pyrogenes. From area $\mathrm{C}$, one sample was positive for the serovar pomona.

All urine samples tested negative on the PCR amplification. All eight rodents were seronegative as well.

\section{DISCUSSION}

To the authors' knowledge, this is the first report of an investigation of leptospirosis in C. lami using serology and PCR. The positive serological results indicated that the $C$. lami had contact with pathogenic leptospires. The source of contamination was unclear, but possible contact with cattle, small mammals or contaminated water should be considered.

Although all of the PCR analyses in urine were negative, the possibility of leptospirosis transmission by $C$. lami cannot be discounted. Moreover, other members of the infraorder Hystricognathi (WILSON \& REEDER, 2005) have been reported to have had positive culture/isolation of leptospires in their kidneys and/or urine: the coypu (Myocastor coypus) in France (MICHEL et al., 2001) and in Great Britain (WAITKINS et al., 1985) and the capybara (Hydrochaeris hydrochaeris) in Brazil (Marvulo et al., 2002, MARVULO et al., 2009, JORGE et al., 2010).

\section{CONCLUSION}

Although $C$. lami may be exposed to Leptospira spp., infection may be occasional because no detectable leptospiruria was found. Whether the tuco-tuco rodents act as reservoirs of the disease remains to be conclusively established.

\section{REFERENCES}

FREITAS, T.R.O. "Tuco-tucos" (Rodentia Octodontidae) in southern Brazil: Ctenomys lami spec. nov. separated from $C$. minutus Nehring 1887. Studies on Neotropical Fauna and Environment, v.36, n.1, p.1-8, 2001.

GRAVEKAMP, C.; VAN DE KEMP, $\mathrm{H}$; FRANZEN, M. et al. Detection of seven species of pathogenic leptospires by PCR using two sets of primers. Journal of General Microbiology, v.139, n.8, p.16911700, 1993.

GUERRA, M.A. Leptospirosis. Journal of the American Veterinary Medical Association, v.234, n.4, p.472-478, 2009.

JORGE, S.; COIMBRA, M.A.A.; LUCAS, C. et al. 2010. Leptospira interrogans isolada de capivara (Hydrochaeris hydrochaeris). In: XIX CIC - XII ENPOS - II Mostra Científica 2010, Pelotas. Anais... Pelotas: 2010, p.14.

LEVETT, P. N. Leptospirosis. Clinical

Microbiology Reviews, v.14, n.2, p.296326, 2001.

LUCCHESI, P.M.A.; ARROYO, G.H.; ETCHEVERRÍA, A.I. et al.

Recommendations for the detection of Leptospira in urine by PCR. Revista da Sociedade Brasileira de Medicina Tropical, v.37, n.2, p.131-134, 2004.

MARVULO, M.F.V.; DE PAULA, C.D.; FERREIRA, P.M. Detection of Leptospira in Two Free Living Populations of Capybaras (Hydrochaeris hydrochaeris) from São Paulo State, Brazil. In: Third Meeting of the International Leptospirosis Society, 2002, Bridgetown. Anais... Bridgetown: [s.n.], 2002.

MARVULO, M.F.; SILVA, J.C.; FERREIRA, P.M. et al. Experimental leptospirosis in capybaras (Hydrochaeris hydrochaeris) infected with Leptospira interrogans serovar Pomona. Journal of Zoo and Wildlife Medicine, v.40, n.4, p.726-730, 2009. 
MICHEL, V.; RUVOEN-CLOUET, N.;

MENARD, A. et al. Role of the coypu

(Myocastor coypus) in the epidemiology of

leptospirosis in domestic animals and

humans in France. European Journal of

Epidemiology, v.17, n.2, p.111-121, 2001.

REIG; O.A.; BUSCH, C.; ORTELLS, M.O. et al. An overview of evolution, systematics, population and speciation in Ctenomys.

Progress in Clinical and Biological

Research, v.335, p.71-96, 1990.

WAITKINS, S.A.; WANYANGU, S.;

PALMER, M. The coypu as a rodent reservoir of leptospira infection in Great

Britain. The Journal of Hygiene, v.95, n.2, p.409-417, 1985.

WILSON, D.E.; REEDER, D.M. Mammal species of the world. A Taxonomic and Geographic Reference. 3.ed. Baltimore: Johns Hopkins University Press, 2005. 2142p. 